\title{
Human Security in East Asia: Beyond Crises
}

\author{
Carolina G. Hernandez, Eun Mee Kim, Yoichi Mine and \\ Ren Xiao
}

\section{Cross-Border Threats to Human Security}

Human beings are all mortal and are vulnerable to risks at various stages of their lifetime. Nobody can be safe from malignant diseases, sudden accidents, loss of job, separation from family and other serious contingencies. While many risks we encounter are idiosyncratic, others are what economists call 'systemic' risks that pounce on groups of people all at once. ${ }^{1}$ A multitude of individuals and households can be adversely affected by a serious and pervasive calamity such as a large-scale natural disaster, an epidemic, a financial crisis or a war. When a risk becomes

C. G. Hernandez $(\bowtie)$

Department of Political Science, University of the Philippines, Quezon City, Philippines

E. M. Kim

Graduate School of International Studies, Ewha Womans University, Seoul, Republic of Korea

Y. Mine

Graduate School of Global Studies, Doshisha University, Kyoto, Japan

R. Xiao

Institute of International Studies, Fudan University, Shanghai, China

(C) The Author(s) 2019

C. G. Hernandez et al. (eds.), Human Security and Cross-Border

Cooperation in East Asia, Security, Development and Human Rights in East Asia, https://doi.org/10.1007/978-3-319-95240-6_1 
reality, it may inflict grave anxieties and acute deprivation on ordinary people, ruining past achievements in human development or the expanded range of choices people have come to enjoy, built up over several decades (Sen 2003).

This introduces the paradigm of human security, a framework of public action to cope effectively with crisis situations that intensify the 'sources of unfreedom' (Sen 1999, 3-4). The goal of human security is to secure basic freedoms for everyone in the face of present and future risks and threats, by combining top-down protection and bottom-up empowerment. The most revolutionary feature of the human security paradigm is that the referent of security has shifted from the state to the individual human being. Layers of government, international organizations, donor agencies, business, civil society, religious communities and other organizations are all expected to contribute to this end: securing freedoms for individual human beings (CHS 2003; Kaldor 2007).

In the present volume, 'East Asia' is defined as a group of nations consisting of the Association of Southeast Asian Nations (ASEAN) countries, China, Japan and South Korea. This region has experienced dynamic economic growth and has enjoyed relative peace in the sense that we have not had large-scale 'hot wars' involving nation-states in recent decades, more precisely, since 1979 (Tønnesson 2017). However, just like the entire global society, the East Asian region has been haunted by a number of serious threats to human security, which have been well examined in works such as Elliott and Caballero-Anthony (2013), Howe (2013), Jonsson (2009), Nishikawa (2010), Peou (2009), Song and Cook (2015), Teh (2012), Tow et al. (2013), and Watson and Pandey (2005). The list of serious threats that the region faces, as well as that of prescriptions to cope with them, are almost endless.

In this introduction, we classify various threats to human security threefold, according to their proximate causes (Tanaka 2015 and Chapter 2 of this volume). The first category is the threats coming from the 'physical system' of the earth. The Pacific Ring of Fire and the Eurasian seismic zone are conducive to massive shakings of the surface of the earth, and to gigantic tsunami when seismic waves run through the ocean, as demonstrated in the Indian Ocean tsunami in 2004 (nearly 250,000 fatalities), the Sichuan Earthquake in 2008 (nearly 90,000 fatalities), and the Great East Japan Earthquake in 2011 (nearly 20,000 fatalities). There are also hundreds of active volcanoes in the region. In addition, typhoons in the Pacific Ocean and cyclones in the Indian Ocean devastate the coastal 
areas of the region very often. In 2008, some foreign countries attempted to organize a military rescue operation into Myanmar when many people were imperiled by Cyclone Nargis (that eventually claimed the lives of more than 140,000). The islands of the Philippines are also shaken by the frequent landfall of typhoons. Finally, there are dire predictions that climate change and resultant floods and droughts may wreak havoc on agricultural production and threaten food security.

The second category is the threats coming from the 'living system,' such as the spread of infectious diseases, many of which are mediated by the organic bodies of humans and animals. Major diseases that have demanded urgent responses in East Asia include human immunodeficiency virus infection and acquired immune deficiency syndrome (HIV/ AIDS), severe acute respiratory syndrome (SARS) and avian flu. A serious disease that broke out in another region, such as the Ebola hemorrhagic fever, could have been transmitted to East Asia in the absence of protective efforts. In the meantime, cases of the Middle East respiratory syndrome coronavirus (MERS-CoV) have been reported in several East Asian countries. Regional cooperation is indispensable to control these epidemics as they spread through the cross-border migration of people and animals, and the circulation of goods. Enhanced connectivity of people and goods may endanger people's health and well-being, given the rapid pace in which the global and regional economy is being integrated.

The third category is those threats directly coming from the 'social system' of human beings, such as wars, violent conflict, terrorism, land grabbing, economic crises, human trafficking and an exodus of refugees. After World War II, the region witnessed major conflicts such as the Korean War, as well as the prolonged wars in Indochina directly involving the USA, Vietnam, Laos, Cambodia and China. The continued division of Korea and the tension in the Taiwan Strait are graphic examples of the lingering legacy of the Cold War, and North Korea's brinkmanship diplomacy toying with nuclear missiles has been a real threat to human security in the region. Setting aside ideological confrontations, serious inequality and ethnic minority issues can be found in the borderlands, for example, in the interior regions of China, Okinawa in Japan, Mindanao in the Philippines, Aceh in Indonesia, and in the South of Thailand. These are all highly sensitive issues in their national political contexts. On the other hand, as the economies in East Asia are more and more closely connected, the effects of a possible economic crisis will be felt in every corner of the region. The idea of a human security that 
attaches a high value to people's welfare was openly advocated by $\mathrm{Mr}$. Keizo Obuchi, the then Foreign Minister of Japan, in Singapore in May 1998 after the Asian Financial Crisis hit the region (Kurusu 2011).

The case study chapters of this book are arranged from those addressing natural disasters to those dealing with human conflicts based on this classification of sources of threats to human security. The earth was formed about 4.6 billion years ago, the first living organisms appeared about 4.0 billion years ago, and the first Homo sapiens was born only about 3 hundred thousand years ago. These ultralong-term historical layers lie behind the three systems of the present age.

At the same time, it is important to note that the hazards emanating from these three systems are closely connected to each other. For example, there is no 'pure' natural disaster; the casualties from natural disasters like floods and earthquakes hinge on the quality of social systems, including self-help activities at the level of neighborhood communities, as well as the quality of environmental planning and civil engineering. Climate change occurs at the level of the physical system but is clearly an outcome of industrial activities of humans. It is also known that a large proportion of the deaths during famines and violent conflicts is due to the outbreak of infectious diseases in relief camps. ${ }^{2}$ Despite these entanglements, as Akihiko Tanaka indicates in Chapter 2, we have a clear division of academic disciplines corresponding to the three systems: the physical system is the subject of physical and chemical sciences and engineering; the living system is studied by biological, medical and ecological sciences; and the social system is researched by the social sciences and the humanities. Human security provides a powerful raison d'etre for multidisciplinary collaboration between experts with those academic backgrounds. Although the three systems (the earth, the ecosystem and human society) can be harmful to individual human beings, it must be noted that they are also beneficial and even indispensable for the prosperity and well-being of the entire human race: natural energy, biodiversity and robust human institutions are all parts of the three systems. We must be prepared, however, to minimize the threats from the same systems for the sake of human survival.

Globalization is a double-edged sword. Enhanced connectivity tends to make global systems insecure and make unexpected shocks felt in every corner of the world, while the same process provides more effective means of ensuring people's security (people use SNS to confirm the safety of family and friends in case of natural disasters, for example) and greater opportunities for mutual learning from the human security 
practice in other places. While a plethora of books and articles has been written about the 'East Asian miracle,' not enough stories have been told about how the same nations are addressing the challenges for human security. This is the void the present book intends to fill.

\section{In Quest of People's Security}

In this section, we explain how the international society embodied in the United Nations (UN) has developed the framework of human security to counter the threats described above. First, the state is expected to play an essential role in securing basic freedoms for citizens in the face of various risks; the question is whether this role is best performed by a Leviathan (Thomas Hobbes) or by a democratic republic (Immanuel Kant). In either case, in a state of nature, states in international relations may cause harm to one another if there are no legal and normative restrictions on state behavior. Kant argued that, for the sake of its own national security, a state voluntarily seeks alliances with other states, to form a 'federation of peoples' to maintain international peace. Following this logic, world states organized the League of Nations in 1920 and the UN in 1945.

While recognizing the primacy of national security and the necessity of international security, in his Perpetual Peace, Kant highlighted the security of individual persons as the ultimate objective of global governance:

The peoples of the earth have thus entered in varying degrees into a universal community, and it has developed to the point where a violation of rights in one part of the world is felt everywhere. The idea of a cosmopolitan right is therefore not fantastic and overstrained; it is a necessary complement to the unwritten code of political and international right, transforming it into a universal right of humanity. (Kant 1970 [originally 1795], 107-8)

Kant was terrified by the 1755 Lisbon earthquake and tsunami and wrote several monographs about scientific causality and people's vulnerability in such a grave natural disaster. The principal goal of government is to realize human rights and security in every part of the world. According to Kant, the ultimate purpose of the principles of national security (based on civil rights) and international security (based on international rights) is to contribute to the assurance of personal security 
(based on cosmopolitan rights). Security of human individuals is not a means to an end, but an end in itself. National security and international security are of critical importance because they can provide powerful means to protect and promote the well-being of people, not the other way around. The international relations of East Asia after the end of World War II are characterized by national independence and vigilance against various forms of colonialism. However, in the twenty-first century, the diversity and the cross-border nature of threats to human security compel regional actors to engage in collaborative actions based on cosmopolitan sympathy and commitment. Sadako Ogata once indicated that 'human security reinforces state security but does not replace it' (Ogata 2003, 5), which means that human security is expected to complement and 'humanize' state security.

The concept of human security was proposed in the Human Development Report 1994 (UNDP 1994) and elaborated further in Human Security Now, the Final Report of the Commission on Human Security, sometimes called the Ogata-Sen Report after the co-chairs of the Commission, Sadako Ogata and Amartya Sen (CHS 2003). Eventually, the concept of human security was formally agreed upon at the UN General Assembly in September 2012. According to the resolution entitled the 'follow-up to Paragraph 143 on human security of the 2005 World Summit Outcome,' the notion of human security includes 'the right of people to live in freedom and dignity, free from poverty and despair. All individuals, especially vulnerable people, are entitled to freedom from fear and freedom from want, with an equal opportunity to enjoy all their rights and fully develop their human potential.' Human security is therefore to address 'widespread and cross-cutting challenges' with 'people-centered, comprehensive, context-specific and prevention-oriented' methods, strengthening 'the protection and empowerment of all people and all communities.' And, human security 'is distinct from the responsibility to protect and its implementation' (UNGA 2012).

At the turn of the last century, the notion of responsibility to protect (R2P) was popular as a 'narrow' interpretation of the idea of human security. Elaborated under the leadership of the Canadian government, the R2P was meant to relate the concept of human security exclusively to freedom from fear (preventing genocide, war crime, ethnic cleansing, and other gross and wide-scale violation of human rights). The R2P was eventually separated from the 'comprehensive' understanding of human security, which has been recognized as the legitimate interpretation 
of human security in the UN (UNGA 2012). Contrary to the conventional understanding, however, it must be remembered that the principle of R2P also paid respect to national ownership at least on paper. The influential report of the International Commission on Intervention and State Sovereignty (ICISS) maintains that 'prevention is the single most important dimension' of the R2P (ICISS 2001, xi), and successive UN documents confirm that each state has the responsibility to protect its own citizens and that the international society is obliged to assist states to develop that protective capacity (UNGA 2005, paras 138 and 139; UNGA 2009). In the R2P discourse, military intervention is considered only the last resort, and development cooperation in ordinary times is considered effective in preventing conflict by providing incentives for adversarial parties to collaborate. The R2P has shifted the notion of sovereignty from state 'control' of people in its territory to the state's 'responsibility' to protect its own people.

Given the consensus on definitions, it is becoming critically important to promote further operationalization of the human security concept in international, regional, and national contexts (UNGA 2013). Major learning units of human security practices are thus international organizations, regional organizations, national governments and local communities. As discussed by Kant, a 'gradually expanding federation' of autonomous states is much preferred to a single global monarchy, under which 'laws progressively lose their impact as the government increases its range, and a soulless despotism, after crushing the germs of goodness, will finally lapse into anarchy' (Kant 1970, 105, 113). Even in the Kantian universalist world of cosmopolitan rights, therefore, mutual understanding between independent nations and communities with different cultures, languages and religions remains critically important. The universalism of the UN culminated in the launch of the Sustainable Development Goals (SDGs) in January 2016. Human security is expected to contribute to the realization of the SDGs by ensuring that no one is left behind and directing our attention to the threats that would hamper the expansion of people's freedoms specified as the 17 goals and 169 targets of the SDGs. To this end, a wide variety of non-state actors including NGOs and businesses are expected to collaborate with each other.

The acceptance and diffusion of the comprehensive definition of human security in the East Asian region have been confirmed in a recent research project commissioned by the JICA Research Institute, which demonstrates that East Asian governments, public and private 
organizations and individuals have engaged in a wide variety of practice to address human security, even though many of them do not use the term. The comprehensive understanding of human security consists of several elements with specific keywords: freedom from 'fear' and 'want,' freedom to live in 'dignity,' and combination of 'protection' and 'empowerment.' Even if policy makers and activists have not heard of the concept of human security, practice and legal entitlements relevant to these elements can be easily found in different places in East Asia. As indicated by researchers in Vietnam, human security in East Asia can be 'a jigsaw puzzle, in which the pieces are identified and well grasped, but have not been put together' (Dung and Lan 2015, 27). Regarding responses to serious human security crises, it has been established that East Asians prefer a multilateral or bilateral solution to the unilateral intervention of powerful countries. ${ }^{3}$

\section{Learning from Human Security Practice in East Asia}

There are two kinds of human security practices. First, there can be an 'explicit' human security practice in which policy makers and activists try to apply the idea of human security to solve concrete problems on the ground. The Thai government established the 'Ministry of Social Development and Human Security' in 2002 to advance the welfare of vulnerable people, even though the appropriateness of this naming was not thoroughly discussed; the Philippine government and civil society hotly debated on anti-terrorist 'Human Security Act' in the mid-2000s; and the Japanese university students launched a non-profit organization (NPO) called 'Human Security Forum' and have engaged in post-disaster regeneration of tsunami-affected communities since 2011. Second, as indicated above, there are a wider range of 'implicit' human security practices, in which people address human security issues (threats to human survival emanating from the three systems discussed earlier) to secure freedoms for everybody, especially for vulnerable people, without using, or even not knowing, the concept of human security. The discussion of this book covers the latter category of 'implicit' public action for human security.

Then, how can we draw concrete lessons from such a broad range of activities in East Asia? Even though a consensus on the basic definition of human security has been reached in the UN, its concept is yet to be fleshed out both practically and theoretically. To this end, a team 
of East Asian researchers of human security (the present editors of this book) organized a set of case studies that were intended to answer common research questions: (1) how to deal with national sovereignty when pressing human needs arise, (2) how to provide comprehensive support rather than give aid in piecemeal ways, and (3) how to promote bottom-up empowerment in the field in addition to top-down protection. This set of three research questions is based on the perception that the practice of human security is still largely state-centric, piecemeal and protection-oriented in East Asia as well as in the world. We now look a little more closely at these three research questions in turn.

\section{How Should We Deal with the Issue of Sovereignty in the Case of Humanitarian Emergencies?}

The practice of securing human security always involves international efforts. The aid-giving side and the aid-receiving side may have different expectations and take incompatible or contradictory actions. There are even extreme cases in which an external actor intends to give support to local people in an emergency, but the national government refuses to allow its operation. Such a contradiction often boils down to the question of apparent trade-offs between national sovereignty and humanitarian needs.

Although this tension has been the central theme of the debate over humanitarian intervention in the $\mathrm{R} 2 \mathrm{P}$ framework for many years, the same contradiction may arise in crisis situations triggered by natural disasters, infectious diseases and other non-conflict crises. While a possibility of military intervention into a sovereign land provokes a very strong reaction in East Asia people at the grass-roots levels tend to accept assistance even of uniformed foreign soldiers in case of natural disasters. Yet the pros and cons must be discussed further in both political and local contexts. Even though the needs of human security and national security may appear adversarial, in the real world there are infinite gradations from one extreme in which a powerful state takes a full role to protect the security of its own citizens to the other extreme in which outside actors rescue people from the menace of a criminal state. This book attempts to draw lessons from cases in which foreign actors tried to reach out to the people in need of assistance, faced difficulties, and eventually found some solutions in their operations, even though nation-states can also play positive roles in realizing human security (Bae and Maruyama 2015). 


\section{How Can We Make Stakeholder Support More Comprehensive?}

Threats are interdependent. For example, when persistent poverty is understood to lead to violent conflicts, this causality requires close cooperation among the practitioners engaged in various issues of development and peace, ranging from income generation, provision of clean water, infrastructure development, legal system reform, security sector reform to peace education. The Human Development Report 1994 sets forth seven areas of human security, i.e., economic, food, health, environmental, personal, community and political security (UNDP 1994), and this categorization was meant for a greater collaboration among various UN organs and specialized agencies. ${ }^{4}$ The practice of human security should go beyond sectionalism and turf wars among various stakeholders and avoid duplication, as well as the absence, of necessary aid. This principle applies to national and international levels equally.

In view of providing more comprehensive, holistic support to those who suffer human insecurities on the ground, many chapters of this book discuss issues related to the coordination by multiple sectors and actors including government ministries, local and national governments, military, non-governmental organizations (NGOs), foreign agencies, etc. In the context of donor coordination in post-conflict state building, Roland Paris described a possible trade-off between inclusiveness of horizontal collaboration and efficiency of hierarchical decision making (Paris 2009). Human security action invites more actors to get out of their own comfortable 'silos' and collaborate with each other, but the task for their coordination can be complicated.

In East Asia where the national security perspective historically prevails, non-military threats have been widely discussed in light of non-traditional security (NTS) goals (Caballero-Anthony et al. 2006). The NTS perspective also emphasizes the multiplicity of security providers and largely overlaps the human security perspective. However, while 'Human Security puts people, and not the state, at the center, Non-traditional Security recognizes both the state and the individual as objects of security' (Caballero-Anthony 2016, 14). ${ }^{5}$

\section{How Can We Promote Bottom-Up Empowerment?}

Although combining protection and empowerment is a hallmark of the comprehensive approach to human security, the former still tends to 
dominate the discussion about the actual practice in promoting human security. In the real world, protective actions without due regard to local contexts may unintentionally exacerbate conflict situations in the field of international aid (Anderson 1999). Many of the chapters in this book, therefore, attempt to promote discussion of ways of empowering local stakeholders to restore the balance.

In this connection, three points seem to be crucial. First, the problem-solving ability of multiple layers of communities and institutions should be enhanced using research and the best practices in capacity development (Fukuda-Parr et al. 2002). Second, given the diversity of people and their living conditions, attention should be paid to the differential vulnerabilities to downside risks, which affect everybody and yet cause damage to certain groups of people more than others: aged and disabled people tend to be left behind in case of tsunami, for example. Air pollution affects the lungs of haves and have-nots equally, but it is often the poor population living in lowlands who are washed away at the time of a cyclone. The logics of risk and class are thus intertwined (Beck 1992). Third, paying respect to the dignity of people who face human insecurity must be of prime importance in promoting empowerment. This element of dignity is the last addition to the concept of human security and has started to attract attention from aid practitioners and thinkers. ${ }^{6}$

Regional and subnational dimensions are important in human security practice. But, it must also be noted that respect for national dignity and culture is essential for successful collaboration for human security. In the East Asian context, the salience of nationalism is partly due to the history of colonial domination by the Western powers and Japan that devastated the region and deprived people and communities of dignity. This factor should be seriously considered despite the robust growth of the regional economy in recent years.

\section{The STructure of THE Book}

The main body of this book consists of case studies that are arranged according to the classification of the sources of threats to human security from the physical system, the living system to the social system. While every case study addresses all the research questions described above, a relatively strong focus is usually put on one or two of them. The risks discussed in this book are serious matters of global (or regional) concern. 
This means that a purely 'domestic' issue that a national government can address on its own is outside the scope of our joint research. The case studies pay attention to the experiences of aid-giving and aid-receiving countries as well as of regional cooperation to varying degrees.

Let us provide summaries of the chapters that follow this introduction. Chapter 2 (Akihiko Tanaka) offers a theoretical introduction to the volume vis-à-vis the nature of human security threats. It provides an interdisciplinary framework in which key aspects of human security are systematically laid out: a typology of threats based on the distinction between the physical, living and social systems, as well as the causality of multiple threats. Then, the chapter discusses various measures to address these threats, and finally, it examines the issues of agency for protecting human security.

Chapter 3 (Wooyeal Paik) discusses the 2008 Great Sichuan Earthquake in China. Beijing's decision to accept foreign humanitarian aid during the rescue period was occasioned by China's greater political and economic capacity and resultant self-confidence. At the same time, the Chinese government was concerned about the possibility that some anti-regime forces might take advantage of the presence of foreigners. The author argues that this political logic has important implications for human security in disaster situations and proposes practical ways to deliver aid to people without downplaying nationalist consciousness. In a similar vein, examining the experience of the Great East Japan Earthquake in 2011, Chapter 4 (Oscar A. Gómez) indicates that conventional aid such as sending relief goods and rescue teams may be of little use, sometimes even burdensome. Declining useless relief should not be denounced but normalized. Non-conventional aid such as special skills to deal with the nuclear accident appeared more useful in this case, although these forms of aid require coordination and preparation in peacetime. Forging grass-roots solidarity is effective in the longer term.

A natural disaster may fuel or appease local human conflict, and this puzzling situation typically unfolded in the case of Aceh, Indonesia, where a long-term violent conflict 'collided' with a massive tsunami in 2004. Chapter 5 (Vidhyandika Djati Perkasa) argues that, with the 'opening' of the area, the Indonesian military was suspicious about foreign invasion under the pretext of 'humanitarian aid.' There were different coordination problems in the emergency period and in the reconstruction period. The author's anthropological research also reveals that Gampong, the smallest community unit, has been effective in 
empowering the people. In the real world, coordination and empowerment in both response and recovery periods seem to have been hindered in chronic conflict situations.

The next two chapters discuss the ravages of huge storms. Chapter 6 (Brendan M. Howe) tells the story of Cyclone Nargis that hit the coastal area of Myanmar in 2008, and which brought to light sharp tensions between the state sovereignty of Myanmar and the human security needs on the ground. There seems to be comparative advantages of Asian approaches to human security: diplomatic engagement rather than intervention has tended to work when dealing with authoritarian regimes in East Asia. The disaster also exposed dramatic disconnects between the military authorities and civil society. The need for building community resilience is also emphasized. In contrast, Chapter 7 (Perlita M. FragoMarasigan) discusses the case of a similar disaster hitting a relatively open, democratic nation: the Philippines. In 2013, parts of the country were devastated by Typhoon Haiyan. This chapter illuminates both the strength and weakness of local communities through bottom-up research including focus group discussions. The chapter reflects on contrasting experiences in different municipalities and sheds light on the significance of strengthening the disaster preparedness of the government.

Emerging infectious diseases are real threats to human security. Their impact is typically cross-border, requiring global collective action to control the spread of bioagents. Chapter 8 (Shunji Cui) addresses the outbreak of the Ebola virus disease (EVD) in West Africa that became one of the worst disease-driven humanitarian crises in modern history. China has played a significant role in the global fight against Ebola, indicating important changes in its foreign policy orientations. Based on lessons drawn from China's operations, it is argued that states must transcend their narrow national interests and consider seriously the dignity and well-being of vulnerable people.

Then, we discuss various aspects of human insecurities pertaining to the social system in East Asia. As illustrated in Chapter 9 (Pou Sovachana and Paul Chambers), land grabbing has become a crisis of enormous proportions in contemporary Cambodia. A great number of people have been robbed of their lands in violent circumstances. This chapter chronicles how land grabbing in Cambodia began and why it has continued to grow and examines three case studies in rural and urban locations. Recognizing the primacy of people's empowerment, the chapter presents recommendations to the state, civil society and international 
stakeholders. Chapter 10 (Sachiko Ishikawa and Dennis Quilala) demonstrates that the protracted conflict in Mindanao has not reached a peaceful resolution despite many decades of domestic and international efforts. Against the backdrop of local history, JICA's involvement in peacemaking beyond its traditional mandate is analyzed. Then, the grass-roots perceptions of JICA's activities are examined. Development practitioners should facilitate peace processes that would fit local realities.

Finally, the book concludes with case studies of people's movement. Contrasting human security with national security, Chapter 11 (Shin-wha Lee) examines South Korea's policies toward global refugees and North Korean defectors, an effective indicator of regime instability. It is argued that security and welfare of individual persons, which are the very reason for the existence of a sovereign state, must be prioritized in human security practice. The policy development in this regard is essential for a middle-power nation like South Korea. Chapter 12 (Surangrut Jumnianpol, Nithi Nuangjamnong and Sompong Srakaew) illustrates what a regional organization can and should do to put an end to human trafficking. Thousands of fishermen have fallen prey to human traffickers and been found on distant Indonesian islands. The authors distinguish several categories of sovereignty and argue that the affected ASEAN countries should compromise some principle of sovereignty to address international crime effectively. Rehabilitation, justice and public awareness are much needed to tackle the issue, and all these activities should be coordinated by ASEAN.

Chapter 13 (Carolina G. Hernandez, Eun Mee Kim, Yoichi Mine, Ren Xiao and Ako Muto) gives a cross-country analysis and draws lessons from all case study chapters according to the three research questions: sovereignty, coordination and empowerment. In addition to theoretical and conceptual insights, a set of policy implications for human security practitioners is presented. Finally, it is demonstrated that human security in East Asia is considered a regional public good (Hernandez 2012).

Although the construction of East Asian regional institutions has been discussed mainly in terms of the ASEAN framework (e.g., Acharya 2014; Beeson 2014; Roberts 2013), it is time to start discussing the possible ways of strengthening regional collaboration for human security in the 'ASEAN Plus Three' framework (10 ASEAN countries plus China, Japan and South Korea). In doing so, we should remember that East Asian nations share some degree of developmentalist attitudes. Although the scope of human security is much wider than economic growth, it 
is nonetheless true that the continuous process of robust growth has provided powerful means to lift people out of poverty and insecurity in the region. Globalization and the resultant connectivity of the East Asian region cause impending human security threats and, at the same time, give rise to collaborative action to address them. While the clouds of nationalist confrontations loom large in East Asia, there are multiple regional dialogues and coordinated actions to tackle cross-border human security challenges. It is, therefore, imperative to draw lessons from the collaborative experience of East Asian nations in the field of human security.

Municipality is not just a branch of the national government, as 'the best school of democracy, and the best guarantee for its success, is the practice of local self-government' (Bryce 1921, 133). Issues pertaining to human security should be resolved primarily at the local level, and authorities at higher levels are required to intervene only when problems could not be effectively addressed by people themselves at the local level. ${ }^{7}$ In order to address human insecurities effectively, it is essential to consolidate multilateral frameworks embodied in the UN system where the idea of human security was born. However, the best school of global governance is the practice of regional governance as we have learned from the chapters in this book.

Although humanitarian crises that require global responses are seen around the world, often exacerbated by extreme and lingering poverty in nations afflicted by the crises, we have identified many cases in which the national governments as well as international and regional organizations have successfully provided necessary support in a culturally and politically sensitive manner with full respect to East Asian regional contexts. The lessons of the East Asian experience of securing human freedoms are now presented to East Asians as well as to the outside world for mutual learning.

\section{Notes}

1. While threats to human security have been mainly discussed in the fields of international relations (IR), political science and security studies, the same challenges have also been taken up in development economics and risk studies. See, for example, World Bank (2001, 2013), JICA (2006), Mine (2007).

2. This point was illuminated in the work of Alex de Waal on the famine experience in Africa (de Waal 1989). Jared Diamond argued that the 
immune system that Europeans acquired through animal husbandry was instrumental in their conquest of the Americas (Diamond 1997).

3. The country papers are available at: http://jica-ri.jica.go.jp/publication/ workingpaper/, accessed on January 26, 2018. A collection of revised and updated versions of these papers is published as Human Security Norms in East Asia (Palgrave Macmillan 2018). Based on this country-based survey of the process of diffusion of the human security norm, we commenced an issue-based inquiry into the human security practice on the ground. The present volume is an outcome of this second phase of the research project.

4. This categorization of seven areas is a convenient way to illustrate human security issues, but the challenge is to know how those security areas are related to each other.

5. 'Comprehensive security' also addresses multiple threats, but in this framework the chief security providers are clearly the national governments.

6. The potential of the dignity concept started to be discussed only after CHS (2003). Tadjbakhsh and Chenoy (2008) tried to go beyond 'fear and want.'

7. This principle is called 'subsidiarity' and embedded in the EU law. The principle seems to be very useful when we understand the relationship between protection and empowerment.

\section{REFERENCES}

Acharya, Amitav. 2014. Constructing a Security Community in Southeast Asia: ASEAN and the Problem of Regional Order. 3rd ed. Abingdon, Oxon: Routledge.

Anderson, Mary B. 1999. Do No Harm: How Aid Can Support Peace-Or War. Boulder: Lynne Rienner.

Bae, Sangmin, and Makoto Maruyama, eds. 2015. Human Security, Changing States and Global Responses: Institutions and Practices. Abingdon, Oxon: Routledge.

Beck, Ulrich. 1992. Risk Society: Towards a New Modernity. London: Sage.

Beeson, Mark. 2014. Regionalism and Globalization in East Asia: Politics, Security and Economic Development. 2nd ed. Basingstoke: Palgrave Macmillan.

Bryce, James. 1921. Modern Democracies: Volume 1. London: Macmillan.

Caballero-Anthony, Mely, ed. 2016. An Introduction to Non-traditional Security Studies: A Transnational Approach. Los Angeles: Sage.

Caballero-Anthony, Mely, Ralf Emmers, and Amitav Acharya, eds. 2006. Nontraditional Security in Asia: Dilemmas in Securitization. Aldershot: Ashgate.

CHS (Commission on Human Security). 2003. Human Security Now. New York: Commission on Human Security. 
De Waal, Alexander. 1989. Famine That Kills: Darfur, Sudan, 1984-1985. Oxford: Clarendon Press.

Diamond, Jared. 1997. Guns, Germs, and Steel: The Fates of Human Societies. New York: W.W. Norton.

Dung, Pham Lan, and Nguyen Ngoc Lan. 2015. 'The Concept of Human Security in Vietnam.' JICA-RI Working Paper No. 100. Accessed January 26, 2018. https://www.jica.go.jp/jica-ri/publication/workingpaper/the_concept_of_human_security_in_vietnam.html.

Elliott, Lorraine, and Mely Caballero-Anthony, eds. 2013. Human Security and Climate Change in Southeast Asia: Managing Risk and Resilience. Abingdon, Oxon: Routledge.

Fukuda-Parr, Sakiko, Carlos Lopes, and Khalid Malik. 2002. Capacity for Development: New Solutions to Old Problems. New York: Earthscan.

Hernandez, Carolina G., ed. 2012. Mainstreaming Human Security in ASEAN Integration: Regional Public Goods and Human Security, Volume 1. Diliman, Quezon City: Institute for Strategic and Development Studies.

Howe, Brendan. 2013. The Protection and Promotion of Human Security in East Asia. Basingstoke: Palgrave Macmillan.

ICISS (International Commission on Intervention and State Sovereignty). 2001. The Responsibility to Protect: Report of the International Commission on Intervention and State Sovereignty. Ottawa: International Development Research Centre.

JICA (Japan International Cooperation Agency). 2006. Poverty Reduction and Human Security: Incorporating the Concept of Human Security into Poverty Reduction. Tokyo: Institute for International Cooperation, JICA.

Jonsson, Anna, ed. 2009. Human Trafficking and Human Security. London: Routledge.

Kaldor, Mary. 2007. Human Security: Reflections on Globalization and Intervention. Cambridge: Polity.

Kant, Immanuel, and Hans Siegbert Reiss, ed. 1970. Kant: Political Writings. Cambridge: Cambridge University Press.

Kurusu, Kaoru. 2011. 'Japan as an Active Agent for Global Norms: The Political Dynamism Behind the Acceptance and Promotion of "Human Security".' Asia-Pacific Review 18 (2): 115-37.

Mine, Yoichi. 2007. 'Downside Risks and Human Security.' In Protecting Human Security in a Post 9/11 World: Critical and Global Insights, edited by Giorgio Shani, Makoto Sato, and Mustapha Kamal Pasha, 64-79. Basingstoke: Palgrave Macmillan.

Nishikawa, Yukiko. 2010. Human Security in Southeast Asia. Abingdon: Routledge. 
Ogata, Sadako. 2003. 'Human Security and State Security.' In Human Security Now, edited by Commission on Human Security, 5. New York: Commission on Human Security.

Paris, Roland. 2009. "Understanding the "Coordination Problem" in Postwar Statebuilding.' In The Dilemmas of Statebuilding: Confronting the Contradictions of Postwar Peace Operations, edited by Roland Paris and Timothy D. Sisk, 53-78. London: Routledge.

Peou, Sorpong, ed. 2009. Human Security in East Asia: Challenges for Collaborative Action. Abingdon, Oxon: Routledge.

Roberts, Christopher B. 2013. ASEAN Regionalism: Cooperation, Values and Institutionalisation. Abingdon, Oxon: Routledge.

Sen, Amartya. 1999. Development as Freedom. New York: Alfred A. Knopf.

Sen, Amartya. 2003. 'Development, Rights and Human Security.' In Human Security Now, edited by Commission on Human Security, 8-9. New York: Commission on Human Security.

Song, Jiyoung, and Alistair D.B. Cook, eds. 2015. Irregular Migration and Human Security in East Asia. Abingdon, Oxon: Routledge.

Tadjbakhsh, Shahrbanou, and Anuradha M. Chenoy. 2008. Human Security: Concepts and Implications. London: Routledge.

Tanaka, Akihiko. 2015. 'Toward a Theory of Human Security.' JICA-RI Working Paper, No. 91. Accessed January 26, 2018. https://www.jica.go.jp/ jica-ri/publication/workingpaper/toward_a_theory_of_human_security.html.

Teh, Benny Cheng Guan, ed. 2012. Human Security: Securing East Asia's Future. Dordrecht: Springer.

Tønnesson, Stein. 2017. Explaining the East Asian Peace: A Research Story, Copenhagen: NIAS Press.

Tow, William T., David Walton, and Rikki Kersten, eds. 2013. New Approaches to Human Security in the Asia-Pacific: China, Japan and Australia. Farnham: Ashgate.

UNDP (United Nations Development Programme). 1994. Human Development Report 1994. Oxford: Oxford University Press.

UNGA (United Nations General Assembly). 2005. 2005 World Summit Outcome, $A / R E S / 60 / 1$. New York: United Nations.

UNGA (United Nations General Assembly). 2009. Implementing the Responsibility to Protect, A/63/677. New York: United Nations.

UNGA (United Nations General Assembly). 2012. Follow-Up to Paragraph 143 on Human Security of the 2005 World Summit Outcome, A/RES/66/290. New York: United Nations.

UNGA (United Nations General Assembly). 2013. Follow-Up to General Assembly Resolution 66/290 on Human Security, A/68/685. New York: United Nations. 
Watson, Iain, and Chandra Lal Pandey, eds. 2005. Environmental Security in the Asia-Pacific. New York: Palgrave.

World Bank. 2001. World Development Report 2000/2001: Attacking Poverty. Washington, DC: World Bank.

World Bank. 2013. World Development Report 2014: Risk and Opportunity: Managing Risk for Development. Washington, DC: World Bank. 